J Venom Anim Toxins incl Trop Dis, 2019 25: e20190012

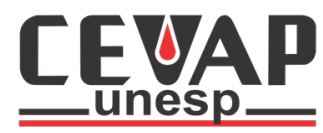

\author{
The Journal of Venomous Animals and \\ Toxins including Tropical Diseases \\ ISSN 1678-9199 \\ Journal homepage www.jvat.org
}

\title{
Is the cat an important reservoir host for visceral leishmaniasis? A systematic review with meta-analysis
}

\author{
Shabnam Asfaram¹, Mahdi Fakhar2,* $\left(\mathbb{D}\right.$, Saeed Hosseini Teshnizi ${ }^{3}$ \\ ${ }^{1}$ Student Research Committee, Department of Parasitology, School of Medicine, Mazandaran University of Medical Sciences, Sari, Iran. \\ ${ }^{2}$ Toxoplasmosis Research Center, Department of Parasitology, School of Medicine, Mazandaran University of Medical Sciences, Sari, Iran. \\ ${ }^{3}$ Infectious and Tropical Diseases Research Center, Hormozgan University of Medical Sciences, Bandar Abbas, Iran.
}

\section{Article Info Keywords:}

Feline leishmanial infection

Global prevalence

Diagnostic tests

Systematic review

Meta-analysis

\begin{abstract}
In recent years feline leishmanial infections (FLI) have been studied more than ever before in various parts of the world. However, evidence-based knowledge on FLI has remained unavailable. The main objectives of this study were to investigate the status of felines infected by Leishmania spp. worldwide. Data were extracted from 10 available databases over the period of 1982 to 2017. Overall, 78 articles fulfilled the inclusion criteria and were used for data extraction in this systematic review. The overall FLI prevalence by both serological and molecular methods was estimated at 10\% (95\% CI: $8 \%-14 \%)$. In Italy, both the seroprevalence (24\%) and PCR prevalence (21 \%) were found to be higher than in other countries. The most common diagnostic test used was the indirect fluorescent antibody test (38.5\%). Studies on mixed-breed felines were more common than those on other breeds, while the most common parasite species was L. infantum (63\%). Our findings suggest that cats act as primary and/or secondary reservoir hosts in the transmission of the Leishmania spp. to humans and also to dogs, by sandflies, at least in endemic foci. Moreover, available data confirm the enzootic stability situation of FLI in several countries including some in Europe.
\end{abstract}

\footnotetext{
* Correspondence: 


\section{Background}

The leishmaniases are neglected protozoal diseases caused by Leishmania spp. that occur in 98 countries [1], affecting 1.2 million in the form of cutaneous leishmaniasis (CL), and 400,000 in the form of visceral leishmaniasis (VL), leading to approximately 40,000 deaths per year [2]. The main route of VL transmission is through the bite of vectors infected with Leishmania donovani (L. donovani) complex, mainly Leishmania infantum/chagasi (L. infantum/chagasi). Both domestic and wild animals may serve as host reservoirs of Leishmania spp. [3]. Dogs are the main reservoir hosts of L. infantum/chagasi but sandflies, as the natural vectors of Leishmania spp., may also feed on the blood of cats [4]. Therefore, cats infected with the $L$. donovani complex may be urban reservoirs of VL and transmit the protozoan to other sandflies [5, 6]; therefore, cats are potential reservoirs of this zoonotic VL disease. Studies on feline leishmanial infection (FLI) are limited and several aspects of the disease in cats are still unclear [7]. Recently, reports of FLI have increased dramatically, achieving a prevalence of up to $60 \%$ in certain cat populations [8]. The most common clinical signs reported in FLI include lymphadenomegaly, splenomegaly, weight loss, anorexia, as well as cutaneous, mucocutaneous and ocular lesions [8]. However, in endemic regions such as Mediterranean countries, the subclinical feline infection $L$. infantum/chagasi is common, whereas clinical illness is relatively uncommon [7-8].

Identification of Leishmania amastigotes in aspirated samples of bone marrow, spleen and lymph node is specific and considered the gold standard method for diagnosing FLI. Feline vector-borne pathogens have been increasingly recognized worldwide based on serological and/or molecular epidemiological investigations $[9,10]$. Most epidemiological studies demonstrated the presence of anti-Leishmania antibodies in feline sera by means of different techniques such as indirect fluorescent antibody test (IFAT), enzyme-linked immunosorbent assay (ELISA) or western blot (WB) [10-17]. Polymerase chain reaction (PCR) is recommended preferentially over other diagnostic tests, especially when blood samples and other clinical samples contain a low parasitic burden $[13,16,18,19]$. However little is known in reference to their diagnostic performance in cats with FLI.

Although an effective treatment for symptomatic cats has not yet been established, oral allopurinol administration followed by subcutaneous glucantime has been frequently used as chemotherapy regimens in cats affected by FLI $[7,8,20]$.

However, there is still no available evidence-based knowledge about various epidemiological aspects of FLI. Therefore, the purpose of this study was to determine the global status of the infection in cats and introduce currently used diagnostic laboratory methods.

\section{Methods}

\section{Searching strategy}

This systematic review was performed according to the guidelines of the Preferred Reporting Items for Systematic Reviews and
Meta-Analysis (PRISMA) [21]. To determine the prevalence of FLI, 10 English and Iranian databases including Google Scholar, Pub Med, Science Direct, Web of Science, Scopus, Elm net, Magiran, Barakatkns (formerly Iran medex), Iran doc, and Scientific Information Database (SID) were searched from 1982 to 2017 (36 years). The relevant keywords including "Leishmania spp.", "Leishmania donovani", "Leishmania infantum", "feline leishmaniasis", "feline leishmaniosis", "cat”, "molecular", "PCR”, "serology", "ELISA", "IFAT" were chosen using medical subject headings terms (MESH).

\section{Inclusion and exclusion criteria}

Data were extracted from studies with at least one of the following inclusion criteria: cross-sectional and case-control studies corresponding to determining prevalence of leishmanial infections that evaluated the presence of FLI based on serological and molecular tests among all types of cats. Also, summaries of articles presented as proceedings at conferences, studies that contained no qualified data, experimental studies, review articles, duplicates, and case reports were excluded. The PRISMA flowchart of the study plan is shown in Figure 1. Out of the retrieved articles, 78 papers were eligible for inclusion in this systematic review and meta-analysis. The recorded data included author name, year of publication, country, type of cat, sample size, Lieshmania species, laboratory method, seroprevalence (\%) and PCR prevalence and quality assessment. The above details were extracted separately by two researchers (SA and MF).

\section{Meta-analysis}

For each study, the prevalence and standard error (SE) were determined. We used forest plots to estimate pooled effect sizes and the effect of each study with $95 \%$ confidence intervals. The Cochran Q-test ( $\mathrm{p}$-value $<0.1)$ and the I-squared index were employed to evaluate heterogeneity, with values between $25 \%$ and $50 \%$ as thresholds for low , between $50 \%$ and $75 \%$ for moderate, and above $75 \%$ for high heterogeneity. When heterogeneity was found, a random-effects model (DersimonianLaird model) was applied; if not, a fixed effects model (MantelHaenszel) was utilized to calculate overall effects.

\section{Quality assessment}

The quality of meta-analysis was evaluated with the STROBE checklist. A checklist including 22 items was considered for adequate reporting of observational studies. These items related to the article's title, abstract, introduction, methods, results, and discussion sections. A score under 7 was defined as poor quality, 8 to 17 low, 18 to 28 moderate and more than more 28 high quality [22]. The mean score obtained via the STROBE checklist for 78 analyzed articles was 31 , whereas 28 is considered high quality. Possible publication bias was explored using a funnel plot and Egger's test, which evaluated whether the precision of studies was appropriate for the scale of their effect size. All data analyses were performed using the software Stata, v. 14 (Stata Corp LP, College Station, Texas, USA). 


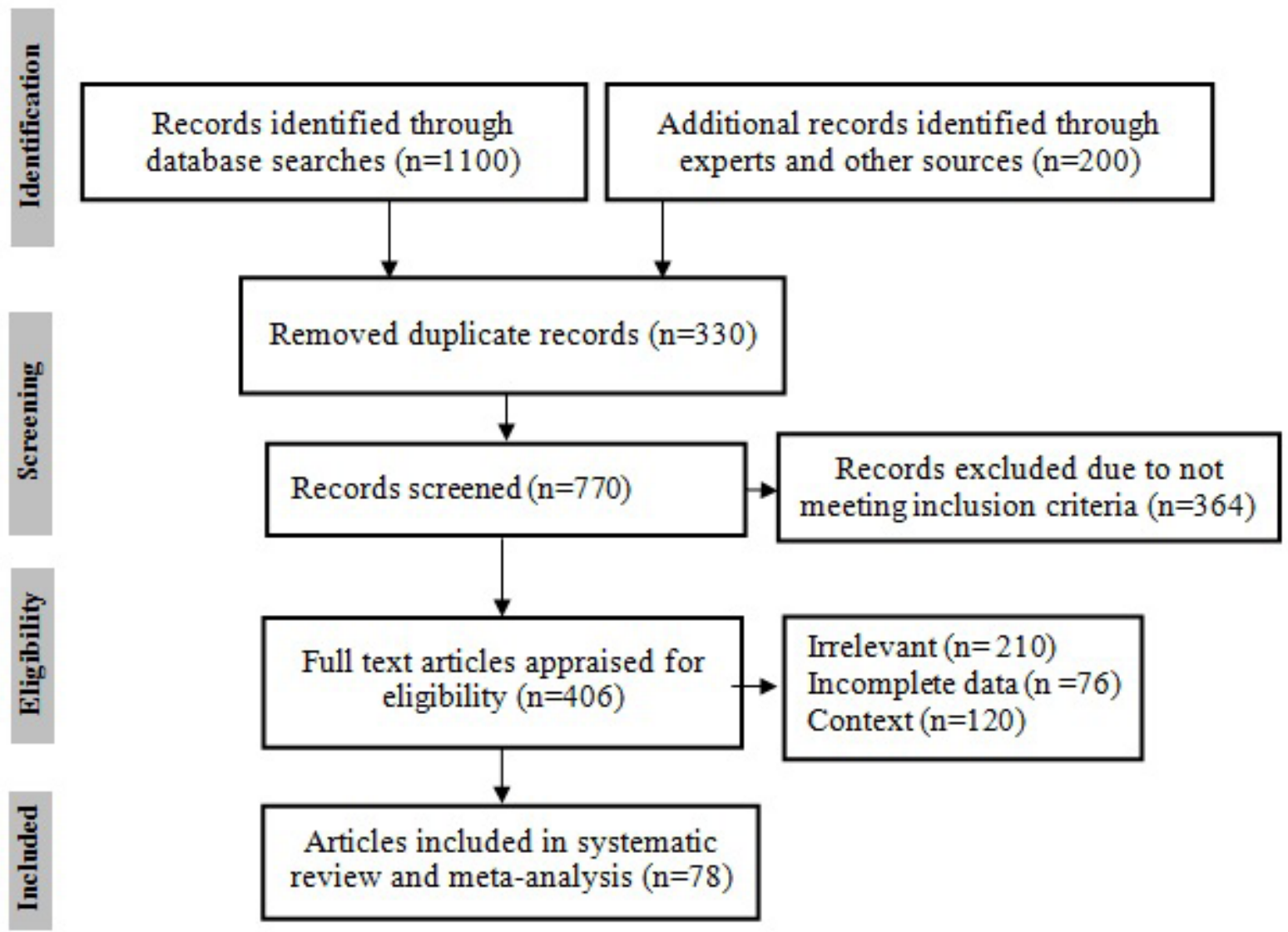

Figure 1. PRISMA flowchart showing the study design process.

\section{Results}

Seventy-eight (78) cross-sectional studies published from 1982 to 2017 (36 years) were included in this meta-analysis. Most studies (30.8\%) were performed in Brazil (Table 1). The total number of cases was 12,635 (ranging from 8 to 1,101). In Italy, both the prevalence by seropositivity (24\%) and PCR positivity (21\%) were found to be higher than in other countries. The overall seropraevalence of FLI in 4 European countries including Italy, Spain, Portugal, and Greece was estimated at $12.2 \%$ (see Table 2).

The most common diagnostic test was IFAT, used in $38.5 \%$ of studies. Among serological methods, WB and indirect hemagglutination test (IHT), being the least common diagnostic tests, were used in only $3.8 \%$ of studies (see Table 1 ).
The seroprevalence (15\%) and PCR prevalence (23\%) of FLI in mixed-type/ breed cats (defined as cats descending from two or more breeds) were higher than in other cat types/ breeds. Approximately $63 \%$ of Leishmania species were L. infantum, while the remainder frequently included Leishmania spp. (Table 2).

The pooled prevalence of FLI based on a random effect metaanalysis ( was estimated at 10\% (9w5\% CI: 8\%-14\%). The estimate of prevalence based on seropositivity (11\%), was significantly higher than PCR positivity (10\%) $(\mathrm{z}=0.01, \mathrm{p}=0.92)$ (Figure 2$)$.

Not only funnel plot but also Egger's test found no evidence a heterogeneity among effect size of studies for seroprevalence $(\mathrm{b}=1.36, \mathrm{p}=0.180)$ and PCR prevalence $(\mathrm{b}=0.16, \mathrm{p}=0.875)$ (see Figure 3).

Table 1. Baseline characteristics of studies included in the meta-analysis of feline leishmanial infection

\begin{tabular}{|c|c|c|c|c|c|c|c|c|}
\hline Author & $\begin{array}{c}\text { Year of } \\
\text { publication }\end{array}$ & Country & $\begin{array}{l}\text { Type } \\
\text { of cat }\end{array}$ & $\begin{array}{l}\text { Sample } \\
\text { size }\end{array}$ & $\begin{array}{l}\text { Leishmania } \\
\text { species }\end{array}$ & Lab test & $\begin{array}{c}\text { Seropositive } \\
\text { (\%) }\end{array}$ & $\begin{array}{c}\text { PCR positive } \\
\text { (\%) }\end{array}$ \\
\hline Michael. SA [43] & 1982 & Egypt & stray & 80 & Leishmania spp. & IHAT & 3.8 & . \\
\hline Morsy. TA [44] & 1988 & Egypt & stray & 28 & Leishmania spp. & IHAT & 3.6 & . \\
\hline Bez. M [45] & 1992 & France & . & 174 & Leishmania spp. & IFAT & 0.6 & . \\
\hline Morsy. TA [46] & 1994 & Egypt & mixed & 60 & Leishmania spp. & IHAT & 10 & . \\
\hline Sherlock. IA [47] & 1996 & Brazil & . & 53 & Leishmania spp. & IFAT & 0 & . \\
\hline Pennisi. MG [48] & 1998 & Italy & mixed & 93 & Leishmania spp. & IFAT & 59.1 & . \\
\hline Ozon. C [29] & 1998 & France & stray & 97 & L. infantum & WB & 12.4 & . \\
\hline
\end{tabular}


Table 1. Cont.

\begin{tabular}{|c|c|c|c|c|c|c|c|c|}
\hline Author & $\begin{array}{c}\text { Year of } \\
\text { publication }\end{array}$ & Country & $\begin{array}{l}\text { Type } \\
\text { of cat }\end{array}$ & $\begin{array}{l}\text { Sample } \\
\text { size }\end{array}$ & $\begin{array}{l}\text { Leishmania } \\
\text { species }\end{array}$ & Lab test & $\begin{array}{c}\text { Seropositive } \\
\text { (\%) }\end{array}$ & $\begin{array}{c}\text { PCR positive } \\
\text { (\%) }\end{array}$ \\
\hline Pennisi. MG [8] & 2000 & Italy & mixed & 89 & Leishmania spp. & IFAT, PCR & 68.5 & 60.7 \\
\hline Poli. A [31] & 2002 & Italy & domestic & 110 & Leishmania spp. & IFAT & 0.9 & . \\
\hline Portús. M [50] & 2002 & Spain & domestic & 117 & L. infantum & ELISA & 1.7 & . \\
\hline Zárate-Ramos. JJ [51] & 2002 & Spain & domestic & 50 & L. infantum & DAT & 42 & . \\
\hline Martín-Sánchez. J [36] & 2007 & Spain & domestic & 183 & L. infantum & IFAT, PCR & 70.5 & 25.7 \\
\hline Nasereddin. A [53] & 2008 & Israel & stray & 104 & Leishmania spp. & ELISA & 6.7 & . \\
\hline Huebner. J [54] & 2008 & Greece & mixed & 389 & Leishmania spp. & IFAT & 21.6 & . \\
\hline Tabar. MD [55] & 2008 & Spain & domestic & 100 & L. infantum & PCR & . & 3 \\
\hline Ayllon. T [40] & 2008 & Spain & domestic & 233 & L. infantum & IFAT, PCR & 4.29 & 0.4 \\
\hline Figueiredo. FB [11] & 2009 & Brazil & . & 43 & Leishmania spp. & IFAT, ELISA & 2.4 & . \\
\hline Hatam. GR [59] & 2010 & Iran & domestic & 40 & L. infantum & PCR & . & 7.5 \\
\hline Veronesi. F [60] & 2010 & Italy & mixed & 95 & Leishmania spp. & IFAT, PCR & 9.5 & 5.3 \\
\hline Cardoso. L [35] & 2010 & Portugal & domestic & 316 & L. infantum & ELISA, DAT & 2.8 & . \\
\hline Duarte. A [61] & 2010 & Portugal & stray & 180 & L. infantum & IFAT & 0.6 & . \\
\hline Maia. C [62] & 2010 & Portugal & domestic & 142 & L. infantum & IFAT, PCR & 1.3 & 20.4 \\
\hline Costa. TA [63] & 2010 & Brazil & . & 200 & L. infantum & ELISA & 11.5 & . \\
\hline Dahroug. MA [64] & 2010 & Brazil & $\begin{array}{c}\text { Puma } \\
\text { concolor, } \\
\text { Panthera } \\
\text { onca, } \\
\text { Leopardus } \\
\text { pardalis }\end{array}$ & 16 & L. infantum & PCR & . & 37.5 \\
\hline Da Silveira Neto. L [ 68] & 2011 & Brazil & . & 113 & L. infantum & ELISA & 34.5 & . \\
\hline Coelho. WM [13] & 2011 & Brazil & . & 70 & Leishmania spp. & IFAT, ELISA & 4.2 & . \\
\hline Coelho. WM [13] & 2011 & Brazil & . & 52 & L. infantum & PCR & . & 5.8 \\
\hline Pennisi. MG [69] & 2012 & Italy & mixed & 431 & Leishmania spp. & IFAT, PCR & 6.9 & 18.3 \\
\hline Ayllon. T [70] & 2012 & Spain & mixed & 680 & L. infantum & IFAT, PCR & 3.7 & 0.6 \\
\hline Sobrinho. LS [14] & 2012 & Brazil & stray & 302 & L. infantum & IFAT, ELISA & 15.23 & . \\
\hline Longoni. SS [17] & 2012 & Mexico & stray & 95 & $\begin{array}{l}\text { L. infantum, } \\
\text { L. braziliensis }\end{array}$ & ELISA, WB & 31.6 & . \\
\hline Spada. E [71] & 2013 & Italy & stray & 233 & Leishmania spp. & IFAT, PCR & 25.3 & 0 \\
\hline Vilhena. H [9] & 2013 & Portugal & domestic & 320 & L. infantum & PCR & . & 0.3 \\
\hline Cardia. DF [72] & 2013 & Brazil & stray & 386 & Leishmania spp. & IFAT & 0.5 & . \\
\hline Silva. RD [73] & 2013 & Brazil & . & 153 & L. infantum & ELISA & 3.9 & . \\
\hline Chatzis. MK [10] & 2014 & Greece & domestic & 100 & L. infantum & $\begin{array}{l}\text { IFAT, ELISA, } \\
\text { PCR }\end{array}$ & 11 & 41 \\
\hline Silaghi. C [74] & 2014 & Albania & stray & 146 & Leishmania spp. & IFAT, PCR & 0.7 & 0 \\
\hline Miró. G [75] & 2014 & Spain & stray & 346 & L. infantum & IFAT, PCR & 3.2 & 0 \\
\hline Maia. C [76] & 2014 & Portugal & mixed & 649 & L. infantum & PCR & . & 9.9 \\
\hline Maia. C [76] & 2014 & Portugal & mixed & 271 & L. infantum & DAT & 3.7 & . \\
\hline Nimsuphan. B [77] & 2014 & Bangkok & pet & 237 & L. donovani & DAT & 0.8 & . \\
\hline Moreno.l [78] & 2014 & Spain & stray & 43 & L. infantum & IFAT & 9.3 & . \\
\hline Dorbadam. SM [79] & 2014 & Iran & stray & 50 & L. infantum & DAT & 2 & . \\
\hline
\end{tabular}


Table 1. Cont.

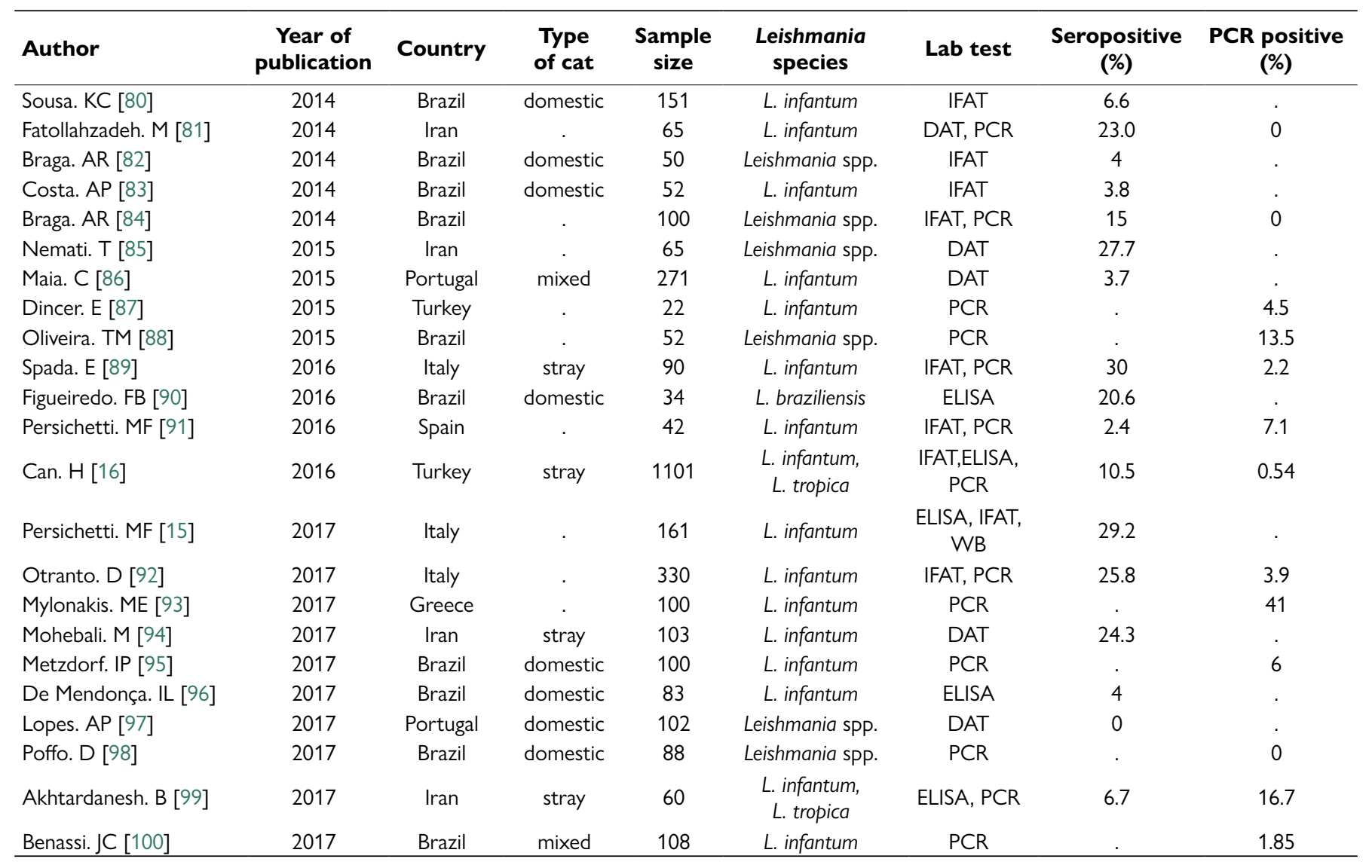

Table 2. Subgroup meta-analysis for seroprevalence and PCR prevalence of Leishmania infection in cats

\begin{tabular}{|c|c|c|c|c|c|c|c|c|c|}
\hline \multirow[b]{2}{*}{ Characteristics } & \multirow[b]{2}{*}{ Factors } & \multicolumn{4}{|c|}{ Seropositive } & \multicolumn{4}{|c|}{ PCR positive } \\
\hline & & $\mathbf{n}$ & $\begin{array}{c}\text { Prevalence (\%) } \\
(95 \% \mathrm{CI})\end{array}$ & $\begin{array}{c}\text { I-square } \\
(\%)\end{array}$ & $\mathbf{P}$ & $\mathbf{n}$ & $\begin{array}{c}\text { Prevalence (\%) } \\
\text { (95\%Cl) }\end{array}$ & $\begin{array}{c}\text { I-square } \\
\text { (\%) }\end{array}$ & $P<0.001$ \\
\hline \multirow{10}{*}{ Country } & Iran & 6 & $17.0(8.0-28.0)$ & 83.8 & 0.06 & 3 & $6.0(0.0-21.0)$ & - & \\
\hline & Egypt & 3 & $6.0(2.0-10.0)$ & 98.3 & & & NR & - & \\
\hline & Greece & 3 & $11.0(2.0-26.0)$ & 95.2 & & & NE & - & \\
\hline & Italy & 10 & $24.0(13.0-37.0)$ & 97.1 & & 7 & $21.0(10.0-61.0)$ & 99.5 & $P<0.001$ \\
\hline & Spain & 12 & $12.0(4.0-23.0)$ & 97.7 & & 8 & $6.0(1.0-14.0)$ & 96.7 & \\
\hline & Portugal & 7 & $2.0(1.0-4.0)$ & 70.1 & & 4 & $11.0(2.0-26.0)$ & 96.7 & \\
\hline & Brazil & 17 & $8.0(3.0-13.0)$ & 93.7 & & 7 & $5.0(1.0-11.0)$ & 85.3 & \\
\hline & ELISA & 12 & $9.0(5.0-13.0)$ & 87.8 & $P<0.001$ & - & - & - & - \\
\hline & IHAT & 3 & $6.0(2.0-10.0)$ & 97.5 & & - & - & - & \\
\hline & IFAT & 30 & $11.0(6.0-17.0)$ & 97.7 & & - & - & - & \\
\hline \multirow[t]{5}{*}{ Diagnostic test } & IFAT, ELISA & 6 & $11.0(7.0-16.0)$ & 97.5 & & - & - & - & \\
\hline & WB & 3 & $14.0(9.0-20.0)$ & 96.6 & & - & - & - & \\
\hline & DAT & 9 & $10.0(3.0-19.0)$ & 94.9 & & - & - & - & \\
\hline & PCR & 12 & $7.0(3.0-14.0)$ & 93.5 & & - & - & - & \\
\hline & Stray & 22 & $10.0(6.0-14.0)$ & 95.2 & 0.46 & 7 & $2.0(0.0-5.0)$ & 90.5 & \\
\hline \multirow[t]{3}{*}{ Breed of cat } & Domestic & 17 & $7.0(2.0-16.0)$ & 97.6 & & 9 & $8.0(1.0-19.0)$ & 96.8 & $P<0.001$ \\
\hline & Mixed & 13 & $15.0(8.0-24.0)$ & 95.6 & & 16 & $23.0(4.0-50.0)$ & 99.4 & \\
\hline & L. infantum & 36 & $12.0(8.0-17.0)$ & 95.4 & 0.09 & 23 & $8.0(4.0-14.0)$ & 95.9 & \\
\hline \multirow[t]{2}{*}{ Leishmania species } & Leishmania spp. & 25 & $8.0(4.0-14.0)$ & 96.7 & & 9 & $15.0(.5 .0-48.0)$ & 99.4 & $P<0.001$ \\
\hline & $\begin{array}{l}\text { L. infantum, } \\
\text { L. tropica }\end{array}$ & 2 & $10.0(8.0-12.0)$ & 97.1 & & 2 & $1.0(0.0-1.0)$ & - & \\
\hline
\end{tabular}

$\mathbf{N R}=$ not reported, $\mathbf{N E}=$ not enough studies 


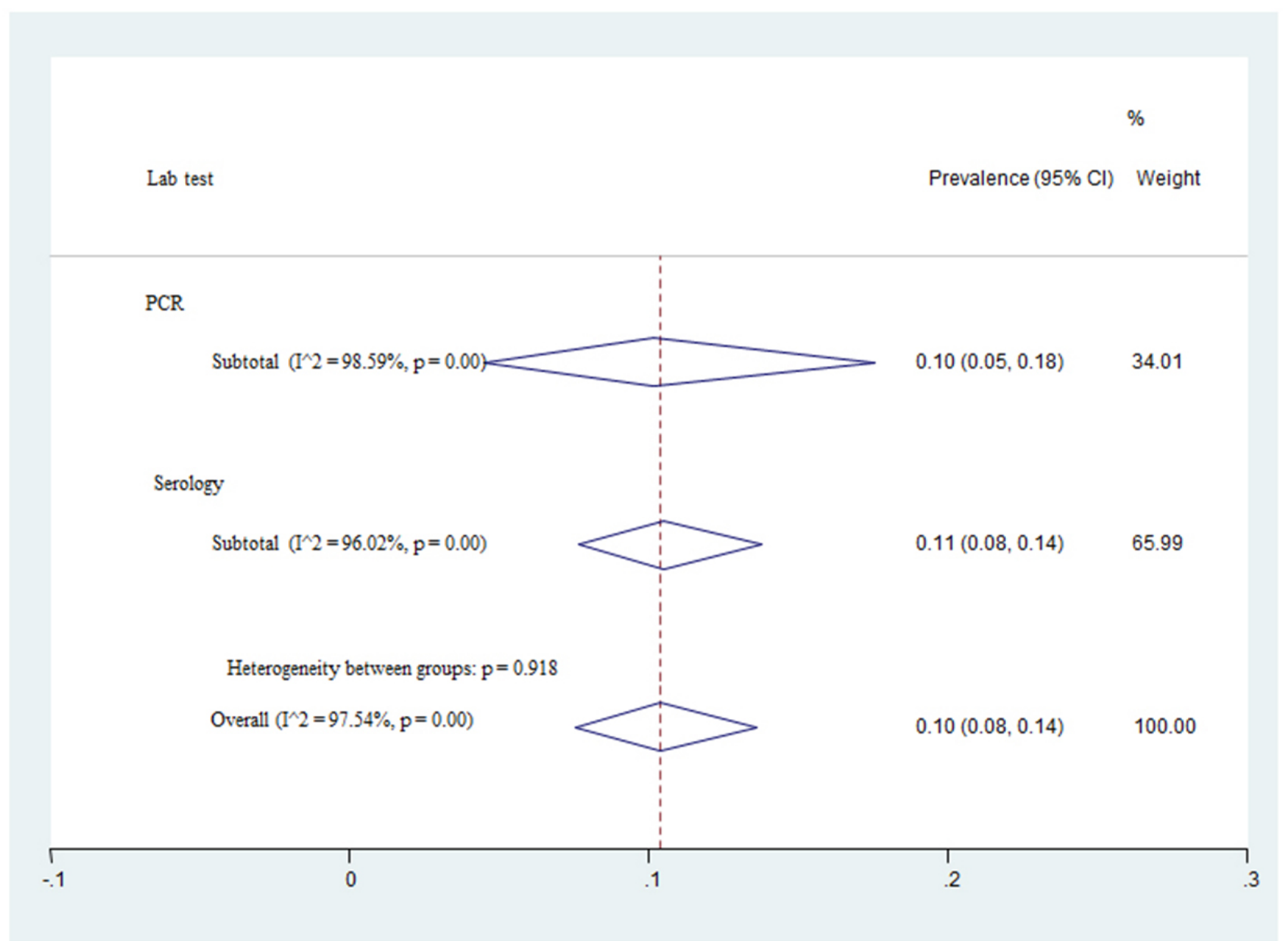

Figure 2. Forest plot for the prevalence of Leishmania infection in cats by PCR and serology tests.

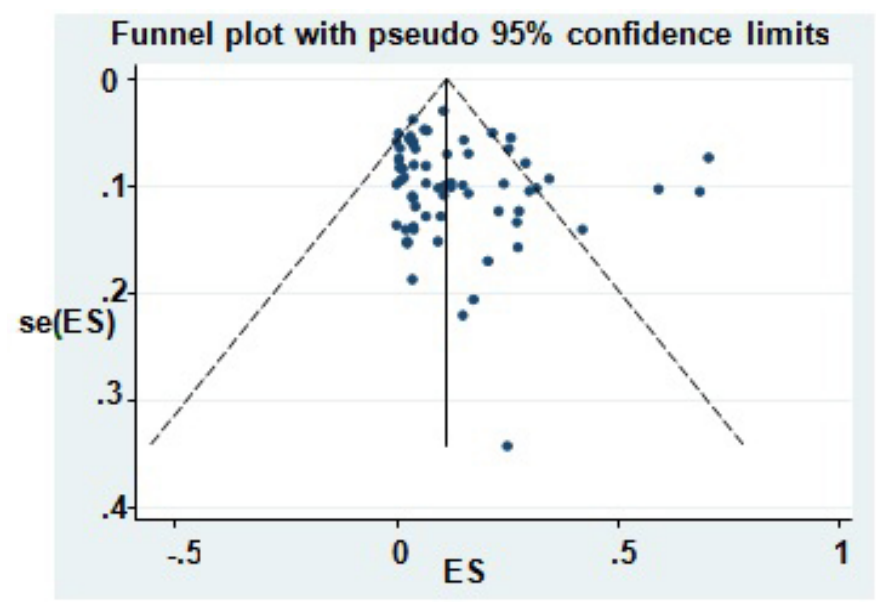

a) Seroprevalence

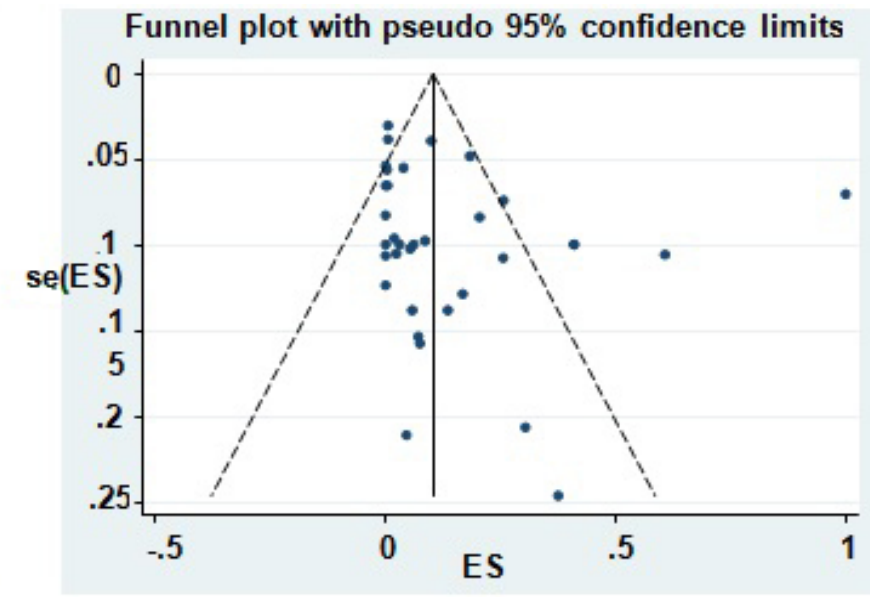

b) PCR prevalence

Figure 3. Funnel plot for seroprevalence (a) and PCR prevalence (b) of Leishmania infection in cats. 


\section{Discussion}

Zoonotic VL (ZVL) is a zoonosis that occurs in the Old and New World. Research studies on FLI are limited but have become more numerous internationally in recent years, especially in Brazil [23]. In this study the highest numbers of reported studies $(30.8 \%)$ were found in Brazil, where leishmaniasis is a major public health problem. Brazil is one of the countries with the highest prevalence and widest geographical distribution of the disease $[2,24]$.

In the current study, the overall prevalence of FLI was estimated to be $10 \%$. The relatively high prevalence of infection in cats demonstrates a similarity with dogs exposed to the leishmanial infections in some endemic areas [25-28 ]. A larger prevalence of L. infantum infection in dogs compared to cats is related to the immune-system differences in these two species and a more efficient Th1 immune response in cats compared to dogs $[25,28]$. The different FLI reports and the increased cat populations in diverse areas highlight the ability of these animals to maintain and spread the infection in natural and urban environments [28]. Overall, little information is available on the adaptive immune response of cats naturally exposed to $L$. infantum infection and mechanisms responsible for susceptibility or resistance of feline hosts. However, some evidence suggests that large numbers of clinical cases of FLI are reported in cats that are probably immunocompromised [8], although it seems that asymptomatic cases have an immunocompetent condition and act as cryptic reservoir hosts.

Based on our findings, FLI in the mixed-type /breed cats were higher than in other feline types/-breeds. The role of domestic cats has been controversial in leishmaniasis epidemiology because they live in close contact with humans. Domestic cats can act as primary, secondary or accidental hosts $[7,28]$.

Seroprevalence rates from $0.9 \%$ to $28.5 \%$ and PCR detection rates between $0.43 \%$ and $30 \%$ have been reported in some regions and countries such as Spain, Portugal, France, and Italy in Southern Europe, as well as in North Africa, Iraq, Iran, Turkey and Central and South America, where canine leishmaniasis is endemic [29-36].

In our study, both seroprevalence (24\%) and PCR prevalence (21\%) of FLI were found higher in Italy than in other countries. Moreover, our data show the high seropraevalence rate (12.2\%) of FLI in Southern European countries including Italy, Spain, Portugal, and Greece. However, this could be justified by the increased finding of active cases in cats, development of simple and rapid diagnostic tests and elevated rate of disease prevalence in these countries.

Diagnosis is usually based on the results of cytology, histopathology, immunohistochemistry (IHC), culture, serology and PCR. Apart from the advantages and limitations inherent to each of these methods, their diagnostic value depends on many factors, including the biological sample being used, the reagents and the particular technique employed.

In our study the most common diagnostic laboratory method was IFAT (38.5\%). IFAT and ELISA are the most common serological techniques used for diagnosis and for clinical and research studies on canine and feline leishmanial infections [10-16]. In areas endemic for Trypanosoma spp. or other Leishmania spp., cross reactions with $L$. infantum must be taken into account for interpretation of serological tests [16]. However, some attention is needed before confirming leishmaniasis with IFAT in cats, whereas cats that present clinical symptoms for leishmaniasis but are found negative by IFAT should be subjected to other serological tests or complementary diagnostic tools such as WB and PCR [7]. WB analysis, a qualitative serological method, distinguishes the molecular weight of the L. infantum antigens stimulating antibody production, but is less frequently used for the diagnosis of leishmaniasis [37]. One potential application of the WB method is the discrimination between subclinical and clinical infections [38].

Three different species of Leishmania have been found in cats in Brazil: L. amazonensis [39], L. braziliensis [40] and L. infantum [34, 41]. Five Leishmania species have been reported in cats worldwide, although most cases involved L. infantum [8]. This is in agreement with our findings in the current study in which approximately $63 \%$ of species were L. infantum.

In conclusion, our data provide substantial evidence that cats can be considered sentinel reservoir hosts at least in endemic foci of zoonotic visceral leishmaniasis. Moreover, the current data demonstrate enzootic stability of FLI in several countries of the world particularly in some European countries. Furthermore, our results show the most common lab method for diagnosing FVL is the IFA test. In general, control of cat populations is recommended to reduce the transmission of Leishmania spp. among human populations in the endemic areas especially among nomadic tribes [42].

\section{Acknowledgments}

The authors are grateful to the vice Chancellor of Research and Technology, Mazandaran University of Medical Sciences.

\section{Abbreviations}

Not applicable.

\section{Availability of data and material}

All data extracted and or analyzed during this study are included in this published article.

\section{Funding}

This publication was supported in part by the Coordination for the Improvement of Higher Education Personnel (CAPES) through "Programa Editoração CAPES" - call No. 13/2016, grant No. 0722/2017, record No. 88881.142062/2017-01 and by the National Council for Scientific and Technological Development (CNPq) and Coordination for the Improvement of Higher Education Personnel (CAPES) through "Programa Editorial CNPq/CAPES” call No. 18/2018, grant No. 404770/2018-5. 
Funding for this systematic review was provided by the vice Chancellor of Research and Technology, Mazandaran University of Medical Sciences (grant number: 2794).

\section{Competing interests}

The authors declare that they have no competing interests.

\section{Authors' contributions}

SA wrote the preliminary draft of the manuscript and extracted all data. MF designed all steps of the study and contributed to writing and revising of the final manuscript. SHT contributed to meta-analysis of the extracted data. All authors read and approved the final manuscript.

\section{Ethics approval and consent to participate}

Not applicable.

\section{Consent for publication}

Not applicable.

\section{References}

1. World Health Organization. Control of the leishmaniasis: report of a meeting of the WHO Expert Commitee on the Control of Leishmaniases, Geneva, 2010.

2. Alvar J, Vélez ID, Bern C, Herrero M, Desjeux P, Cano J, et al. Leishmaniasis worldwide and global estimates of its incidence. PloS One. 2012;7(5):e35671.

3. Quinnell RJ, Courtenay O. Transmission, reservoir hosts and control of zoonotic visceral leishmaniasis. Parasitology. 2009;136(14):1915-34.

4. da Silva Sales KG, Costa PL, de Morais RC, Otranto D, Brandão-Filho SP, de Paiva Cavalcanti M, et al. Identification of phlebotomine sand fly blood meals by real-time PCR. Parasit Vectors. 2015;8:230.

5. da Silva SM, Rabelo PF, de Figueiredo Gontijo N, Ribeiro RR, Melo MN, Ribeiro VM, et al. First report of infection of Lutzomyia longipalpis by Leishmania (Leishmania) infantum from a naturally infected cat of Brazil. Vet Parasitol. 2010;174(1-2):150-4.

6. Maroli M, Pennisi MG, Di Muccio T, Khoury C, Gradoni L, Gramiccia M. Infection of sandflies by a cat naturally infected with Leishmania infantum. Vet Parasitol. 2007;145(3-4):357-60.

7. Pennisi MG, Cardoso L, Baneth G, Bourdeau P, Koutinas A, Miró G, et al. LeishVet update and recommendations on feline leishmaniosis. Parasites Vector. 2015;8:302.

8. Pennisi MG, Persichetti MF. Feline leishmaniosis: Is the cat a small dog? Vet Parasitol. 2018;251:131-7.

9. Vilhena H, Martinez-Díaz VL, Cardoso L, Vieira L, Altet L, Francino O, et al. Feline vector-borne pathogens in the north and centre of Portugal. Parasit Vectors. 2013;6:99.

10. Chatzis MK, Leontides L, Athanasiou LV, Papadopoulos E, Kasabalis D, Mylonakis M, et al. Evaluation of indirect immunofluorescence antibody test and enzyme-linked immunosorbent assay for the diagnosis of infection by Leishmania infantum in clinically normal and sick cats. Exp Parasitol. 2014;147:54-9.

11. Figueiredo FB, Bonna IC, Nascimento LD, Costa Td, Baptista C, Pacheco TM, et al. Avaliação sorológica para detecção de anticorpos anti-Leishmania em cães e gatos no bairro de Santa Rita de Cássia, Município de Barra Mansa, Estado do Rio de Janeiro. Rev Soc Bras Med Trop. 2009;42(2):141-5.

12. Vides JP, Schwardt TF, Sobrinho LS, Marinho M, Laurenti MD, Biondo AW, et al. Leishmania chagasi infection in cats with dermatologic lesions from an endemic area of visceral leishmaniosis in Brazil. Vet Parasitol. 2011;178(1-2):22-8.
13. Coelho WM, Richini-Pereira VB, Langoni H, Bresciani KD. Molecular detection of Leishmania sp. in cats (Felis catus) from Andradina municipality, São Paulo State, Brazil. Vet Parasitol. 2011;176(2-3):281-2.

14. Sobrinho LS, Rossi CN, Vides JP, Braga ET, Gomes AA, de Lima VM, et al. Coinfection of Leishmania chagasi with Toxoplasma gondii, Feline Immunodeficiency Virus (FIV) and Feline Leukemia Virus (FeLV) in cats from an endemic area of zoonotic visceral leishmaniasis. Vet parasitol. 2012;187(1-2):302-6.

15. Persichetti MF, Solano-Gallego L, Vullo A, Masucci M, Marty P, Delaunay $P$, et al. Diagnostic performance of ELISA, IFAT and Western blot for the detection of anti-Leishmania infantum antibodies in cats using a Bayesian analysis without a gold standard. Parasit Vectors. 2017;10(1):119.

16. Can H, Döşkaya M, Özdemir HG, Şahar EA, Karakavuk M, Pektaş B, et al. Seroprevalence of Leishmania infection and molecular detection of Leishmania tropica and Leishmania infantum in stray cats of Izmir, Turkey. Exp Parasitol. 2016;167:109-14.

17. Longoni SS, López-Cespedes A, Sánchez-Moreno M, Bolio-Gonzalez ME, Sauri-Arceo CH, Rodríguez-Vivas RI, et al. Detection of different Leishmania spp. and Trypanosoma cruzi antibodies in cats from the Yucatan Peninsula (Mexico) using an iron superoxide dismutase excreted as antigen. Comp Immunol Microbiol Infect Dis. 2012;35(5):469-76.

18. Chatzis MK, Andreadou M, Leontides L, Kasabalis D, Mylonakis M, Koutinas AF, et al. Cytological and molecular detection of Leishmania infantum in different tissues of clinically normal and sick cats. Vet Parasitol. 2014;202(3-4):217-25.

19. Fakhar M, Rahmati B, Gohardehi S, Mohebali M, Akhoundi B, Sharif M, et al. Molecular and seroepidemiological survey of visceral leishmaniasis among humans and domestic dogs in Mazandaran Province, north of Iran. Iran J Parasitol. 2011;6(4):51-9.

20. Basso MA, Marques C, Santos M, Duarte A, Pissarra H, Carreira LM, et al. Successful treatment of feline leishmaniosis using a combination of allopurinol and N-methyl-glucamine antimoniate. JFMS Open Rep. 2016;2(1). 10.1177/2055116916630002.

21. Liberati A, Altman DG, Tetzlaff J, Mulrow C, Gøtzsche PC, loannidis JP, et al. The PRISMA statement for reporting systematic reviews and metaanalyses of studies that evaluate health care interventions: explanation and elaboration. PLoS Med. 2009;6:e1000100.

22. von Elm E, Altman DG, Egger M, Pocock SJ, Gøtzsche PC, Vandenbroucke JP. Strobe Initiative. The Strengthening the Reporting of Observational Studies in Epidemiology (STROBE) statement: guidelines for reporting observational studies. PLoS Med. 2007;4(10):e296.

23. Dantas-Torres F, Simões-Matos L, Brito FD, Figueiredo LA, Faustino MD. Leishmaniose Felina: revisão de literatura. Rev Clín Vet. 2006;11:32-40.

24. Bern C, Maguire JH, Alvar J. Complexities of assessing the disease burden attributable to leishmaniasis. PLoS Negl Trop Dis. 2008;2(10):e313.

25. Day MJ. Cats are not small dogs: is there an immunological explanation for why cats are less affected by arthropod-borne disease than dogs? Parasit Vectors. 2016;9:507.

26. Shokri A, Fakhar M, Teshnizi SH. Canine visceral leishmaniasis in Iran: a systematic review and meta-analysis. Acta Trop. 2017;165:76-89.

27. Fakhar M, Motazedian MH, Asgari Q, Kalantari M. Asymptomatic domestic dogs are carriers of Leishmania infantum: possible reservoirs host for human visceral leishmaniasis in southern Iran. Comp Clin Path. 2012;21(5):801-7.

28. Maia C, Campino L. Can domestic cats be considered reservoir hosts of zoonotic leishmaniasis? Trends Parasitol. 2011;27(8):341-4.

29. Ozon C, Marty P, Pratlong F, Breton C, Blein M, Lelièvre A, et al. Disseminated feline leishmaniosis due to Leishmania infantum in Southern France. Vet Parasitol. 1998;75(2-3):273-7.

30. Baneth G, Solano-Gallego L. Canine Leishmaniosis. In: Infectious Diseases of The Dog and Cat, Greene, C.E. 4th Ed., 2012. p. 738-42.

31. Poli A, Abramo F, Barsotti P, Leva S, Gramiccia M, Ludovisi A, et al. Feline leishmaniosis due to Leishmania infantum in Italy. Vet Parasitol. 2002;106(3):181-91.

32. Martín-Sánchez J, Acedo C, Muñoz-Pérez M, Pesson B, Marchal O, MorillasMárquez F. Infection by Leishmania infantum in cats: epidemiological study in Spain. Vet Parasitol. 2007;145(3-4):267-73. 
33. Ayllon T, Tesouro MA, Amusategui I, Villaescusa A, Rodriguez-Franco F, Sainz Á. Serologic and molecular evaluation of Leishmania infantum in cats from Central Spain. Ann N Y Acad Sci. 2008;1149:361-4.

34. da Silva AV, de Souza Cândido CD, de Pita Pereira D, Brazil RP, Carreira JC. The first record of American visceral leishmaniasis in domestic cats from Rio de Janeiro, Brazil. Acta Trop. 2008;105(1):92-4.

35. Cardoso L, Lopes AP, Sherry K, Schallig H, Solano-Gallego L. Low seroprevalence of Leishmania infantum infection in cats from northern Portugal based on DAT and ELISA. Vet Parasitol. 2010;174(1-2):37-42.

36. Sherry K, Miró G, Trotta M, Miranda C, Montoya A, Espinosa C, et al. A serological and molecular study of Leishmania infantum infection in cats from the Island of Ibiza (Spain). Vector Borne Zoonotic Dis. 2011;11(3):239-45.

37. Solano-Gallego L, Rodríguez-Cortés A, Iniesta L, Quintana J, Pastor J, Espada $Y$, et al. Cross-sectional serosurvey of feline leishmaniasis in ecoregions around the northwestern Mediterranean. Am J Trop Med Hyg. 2007;76(4):676-80.

38. Iniesta L, Gállego M, Portús M. Idiotype expression of lgG1 and lgG2 in dogs naturally infected with Leishmania infantum. Vet Immunol Immunopathol. 2007;119(3-4):189-97.

39. de Souza AI, Barros EM, Ishikawa E, Ilha IM, Marin GR, Nunes VL. Feline leishmaniasis due to Leishmania (Leishmania) amazonensis in Mato Grosso do Sul state, Brazil. Vet Parasitol. 2005;128(1-2):41-5.

40. Schubach TM, Figueiredo FB, Pereira SA, Madeira MF, Santos IB, Andrade $M V$, et al. American cutaneous leishmaniasis in two cats from Rio de Janeiro, Brazil: first report of natural infection with Leishmania (Viannia) braziliensis. Trans R Soc Trop Med Hyg. 2004;98(3):165-7.

41. Savani ES, de Oliveira Camargo MC, de Carvalho MR, Zampieri RA, dos Santos MG, D'Áuria SR, et al. The first record in the Americas of an autochthonous case of Leishmania (Leishmania) infantum chagasi in a domestic cat (Felix catus) from Cotia County, São Paulo State, Brazil. Vet Parasitol. 2004;120(3):229-33.

42. Asgari Q, Fakhar M, Motazedian H. Nomadic kala-azar in South of Iran. Iranian J Public Health. 2006:85-6.

43. Michael SA, Morsy TA, El-Seoud SF, Saleh MS. Leishmaniasis antibodies in stray cats in Ismailiya Governorate, Egypt. J Egypt Soc Parasitol. 1982;12(1):283-6.

44. Morsy TA, Michael SA, Makhlouf LM, el Sibai MM. Leishmania infection sought in non-human hosts in Suez Governorate, Egypt. J Egypt Soc Parasitol. 1988;18(2):539-45.

45. Bez M. La leishmaniose chez le chat: enquête séro-épidémiologique dans les Alpes-Maritimes. Thesis (Veterinary Doctor) -University of Lyon, 1992.

46. Morsy TA, Abou el Seoud SM. Natural infection in two pet cats in a house of a zoonotic cutaneous leishmaniasis patient in Imbaba area, Giza Governorate, Egypt. J Egypt Soc Parasitol. 1994;24(1):199-204.

47. Sherlock IA. Ecological interactions of visceral leishmaniasis in the state of Bahia, Brazil. Mem Inst Oswaldo Cruz. 1996;91(6):671-83.

48. Pennisi MG, Masucci M, Catarsini O. Presenza di anticorpi anti-Leishmania in gatti FIV+ che vivono in zona endemica. Atti Soc Ital Sci Vet. 1998;52:2656.

49. Simões-Mattos L, Mattos MR, Rodrigues TP, Prata-Júnior JR, Teixeira MJ, Silva TF, et al. Survey of anti-Leishmania chagasi antibodies in stray cats (Felis catus) in the city of Fortaleza (Ceará, Brazil). Ciência Animal. 2001;11:79-81.

50. Portús M, Gállego M, Riera MC, Aisa MJ, Fisa R, Castillejo S. Wild and domestic mammals in the life cycle of Leishmania infantum in Southwest Europe. A literature review and studies performed in Catalonia (Spain). Rev Iber Parasitol. 2002;62(3-4):72-6.

51. Zárate-Ramos JJ, Arbea-Sarasa I, Gómez-Ochoa P, Castillo-Hernández JA, García-Salinas MJ, Morales-Amella MJ. Serological evidence of leishmaniasis in cats in Aragon, Spain. In: Proceedings of the 27th WSAVA Congress. Granada: World Small Animal Veterinary Association. 2002.

52. Vita S, Santori D, Aguzzi I, Petrotta E, Luciani A. Feline leishmaniasis and ehrlichiosis: serological investigation in Abruzzo region. Vet Res Commun. 2005;29(Suppl 2):319-21.

53. Nasereddin A, Salant H, Abdeen Z. Feline leishmaniasis in Jerusalem: serological investigation. Vet Parasitol. 2008;158(4):364-9.
54. Huebner J, Müller E, Langbein-Detsch I, Naucke T, Kissingen B. Serological survey of Leishmania infections in cats from north Greece. In: Proceedings of ACVIM Forum. San Antonio. J Vet Intern Med. 2008;22:782-3.

55. Tabar MD, Altet L, Francino O, Sanchez A, Ferrer L, Roura X. Vectorborne infections in cats: molecular study in Barcelona area (Spain). Vet Parasitol. 2008;151(2-4):332-6.

56. Maia C, Nunes M, Campino L. Importance of cats in zoonotic leishmaniasis in Portugal. Vector Borne Zoonotic Dis. 2008;8(4):555-9.

57. Sarkari B, Hatam GR, Adnani SJ, Asgari Q. Seroprevalence of feline leishmaniasis in areas of Iran where Leishmania infantum is endemic. Ann Trop Med Parasitol. 2009;103(3):275-7.

58. Diakou A, Papadopoulos E, Lazarides K. Specific anti-Leishmania spp. Antibodies in stray cats in Greece. J Feline Med Surg. 2009;11(8):728-30.

59. Hatam GR, Adnani SJ, Asgari Q, Fallah E, Motazedian MH, Sadjjadi SM, et al. First report of natural infection in cats with Leishmania infantum in Iran. Vector Borne Zoonotic Dis. 2010;10(3):313-6.

60. Veronesi F, Moretta I, Vitale F, Lupo T, Migliazzo A, Mariani C, et al. Leishmania infantum: serological and molecular investigation in cats from Ischia island. In: Proceedings of the 2nd International Congress on Canine Leishmaniasis. Pisa; 2010. p. 169-71.

61. Duarte A, Castro I, Pereira da Fonseca IM, Almeida V, Madeira de Carvalho LM, Meireles J, et al. Survey of infectious and parasitic diseases in stray cats at the Lisbon Metropolitan Area, Portugal. J Feline Med Surg. 2010;12(6):441-6.

62. Maia C, Gomes J, Cristóvão J, Nunes M, Martins A, Rebelo E, et al. Feline Leishmania infection in a canine leishmaniasis endemic region, Portugal. Vet Parasitol. 2010;174(3-4):336-40.

63. Costa TAC, Rossi CN, Laurenti MD, Gomes AAD, Vides JP, Sobrinho LSV, et al. Ocorrência de leishmaniose em gatos de área endêmica para leishmaniose visceral. Braz J Vet Res Anim Sci. 2010;47(3):213-7.

64. Dahroug MA, Almeida AB, Sousa VR, Dutra $\bigvee$, Turbino NC, Nakazato L, et al. Leishmania (Leishmania) chagasi in captive wild felids in Brazil. Trans R Soc Trop Med Hyg. 2010;104(1):73-4.

65. Bresciani KDS, Serrano ACM, de Matos LVS, Savani ESM, D'Auria SRN, Perri SHV, et al. Ocorrência de Leishmania spp. em felinos do município de Araçatuba, SP. Rev Bras Parasitol Vet. 2010;19(2):127-9.

66. Millán J, Zanet S, Gomis M, Trisciuoglio A, Negre N, Ferroglio E. An investigation into alternative reservoirs of canine leishmaniasis on the endemic island of Mallorca (Spain). Transbound Emerg Dis. 2011;58(4):3527.

67. Miró G, Hernández L, Montoya A, Arranz-Solís D, Dado D, Rojo-Montejo $S$, et al. First description of naturally acquired Tritrichomonas foetus infection in a Persian cattery in Spain. Parasitol Res. 2011;109(4):1151-4.

68. da Silveira Neto L, Sobrinho LS, Martins CO, Machado RZ, Marcondes M, de Lima VM. Use of crude, FML and rK39 antigens in ELISA to detect antiLeishmania spp. antibodies in Felis catus. Vet parasitol. 2011;177(3-4):374-7.

69. Pennisi MG, Lupo T, Malara D, Masucci M, Migliazzo A, Lombardo G. Serological and molecular prevalence of Leishmania infantum infection in cats from Southern Italy. J Feline Med Surg. 2012;14:7.

70. Ayllón T, Diniz PP, Breitschwerdt EB, Villaescusa A, Rodríguez-Franco F, Sainz A. Vector-borne diseases in client-owned and stray cats from Madrid, Spain. Vector Borne Zoonotic Dis. 2012;12(20):143-50.

71. Spada E, Proverbio D, Migliazzo A, Della Pepa A, Perego R, Bagnagatti De Giorgi G. Serological and molecular evaluation of Leishmania infantum infection in stray cats in a nonendemic area in northern Italy. ISRN Parasitol. 2013;2013:916376.

72. Cardia DF, Camossi LG, da Silveira Neto L, Langoni H, Bresciani KD. Prevalence of Toxoplasma gondii and Leishmania spp. infection in cats from Brazil. Vet Parasitol. 2013;197(3-4):634-7.

73. Silva RC, Ramos RA, Pimentel DS, Oliveira GM, Carvalho GA, Santana $M D$, et al. Detection of antibodies against Leishmania infantum in cats (Felis catus) from the State of Pernambuco, Brazil. Rev Soc Bras Med Trop. 2013;47(1):108-9.

74. Silaghi C, Knaus M, Rapti D, Kusi I, Shukullari E, Hamel D, et al. Survey of Toxoplasma gondii and Neospora caninum, haemotropic mycoplasmas and other arthropod-borne pathogens in cats from Albania. Parasit Vectors. 2014;7:62. 
75. Miró G, Rupérez C, Checa R, Gálvez R, Hernández L, García M, et al. Current status of $L$. infantum infection in stray cats in the Madrid region (Spain): implications for the recent outbreak of human leishmaniosis? Parasit Vectors. 2014;7:112.

76. Maia C, Ramos C, Coimbra M, Bastos F, Martins A, Pinto P, et al. Bacterial and protozoal agents of feline vector-borne diseases in domestic and stray cats from southern Portugal. Parasit Vectors. 2014;7:115.

77. Nimsuphan B, Pangjai WC, Cheevasareechon TJ, Jirasutas W. Detection of anti-Leishmania donovani complex antibodies of dogs and cats from Southern Thailand. KKU Vet J. 2014;24

78. Moreno I, Álvarez J, García N, de la Fuente S, Martínez I, Mariño E, et al. Detection of anti-Leishmania infantum antibodies in sylvatic lagomorphs from an epidemic area of Madrid using the indirect immunofluorescence antibody test. Vet Parasitol. 2014;199(3-4):264-7.

79. Dorbadam SM, Akhlaghi L, Akhondi B, Hajjaran H, Zarei Z, Hadighi H. Evaluation of Leishmania infantum in cat by PCR-RFLP in an endemic region of visceral leishmaniasis in meshkin-shahr, Iran. J Genes Microbes Immun. 2014;2014:1-7.

80. Sousa KC, Herrera HM, Domingos IH, Campos JB, Santos IM, Neves $\mathrm{HH}$, et al. Serological detection of Toxoplasma gondii, Leishmania infantum and Neospora caninum in cats from an area endemic for leishmaniasis in Brazil. Rev Bras Parasitol Vet. 2014;23(4):449-55.

81. Fatollahzadeh M, Khanmohammadi M, Bazmani A, Mirsamadi N, Jafari $\mathrm{R}$, Mohebali M, et al. Survey of feline visceral leishmaniasis in Azarshahr area, north west of Iran, 2013. J Parasit Dis. 2016;40(3):683-7.

82. Braga AR, Corrêa AP, Camossi LG, Silva RC, Langoni H, Lucheis SB Coinfection by Toxoplasma gondii and Leishmania spp. in domestic cats (Felis catus) in State of Mato Grosso do Sul. Rev Soc Bras Med Trop. 2014;47(6):796-7.

83. Costa AP, Ferreira JIGS, Fournier GFSR, Lopes MG, Ramirez D, Acosta $I C L$, et al. Survey of Leishmania infantum chagasi in wild and domestic animals in urban area and Atlantic Rainforest fragment. J Biodivers Biopros Dev. 2014;1(2):1-5.

84. Braga AR, Langoni $H$, Lucheis SB. Evaluation of canine and feline leishmaniasis by the association of blood culture, immunofluorescent antibody test and polymerase chain reaction. J Venom Anim Toxins incl Trop Dis. 2014;20:1-7. doi: 10.1186/1678-9199-20-5.

85. Nemati T, Khanmohammadi M, Bazmani A, Mirsamadi N, Koshki MH, Mohebali M, et al. Study on Leishmania infection in cats from Ahar, East Azerbaijan Province and North West Iran by parasitological, serological and molecular methods. Asian Pac J Trop Biomed. 2015;5(1):40-3.

86. Maia C, Ramos C, Coimbra M, Cardoso L, Campino L. Prevalence of Dirofilaria immitis antigen and antibodies to Leishmania infantum in cats from southern Portugal. Parasitol Int. 2015;64(2):154-6.

87. Dincer E, Gargari S, Ozkul A, Ergunay K. Potential animal reservoirs of Toscana virus and coinfections with Leishmania infantum in Turkey. Am J Trop Med Hyg. 2015;92(4):690-7.
88. Oliveira TM, Pereira VF, Benvenga GU, Martin MF, Benassi JC, da Silva DT, et al. Conjunctival swab PCR to detect Leishmania spp. in cats. Rev Bras Parasitol Vet. 2015;24(2):220-2.

89. Spada E, Canzi I, Baggiani L, Perego R, Vitale F, Migliazzo A, et al. Prevalence of Leishmania infantum and co-infections in stray cats in northern Italy. Comp Immunol Microbiol Infect Dis. 2016;45:53-8.

90. Figueiredo FB, Nascimento LD, de Vasconcelos TCB, de Fátima Madeira $M$, Confort EM, Schubach TMVP. Serological diagnosis of feline tegumentary leishmaniasis by indirect immunofluorescence (IFI) and enzyme-linked immunosorbent assay (ELISA) in an endemic area in Brazil. Acta Sci Vet. 2016;44(2016):1-7.

91. Persichetti MF, Solano-Gallego L, Serrano L, Altet L, Reale S, Masucci M, et al. Detection of vector-borne pathogens in cats and their ectoparasites in southern Italy. Parasit Vectors. 2016;9:247.

92. Otranto D, Napoli E, Latrofa MS, Annoscia G, Tarallo VD, Greco G, et al. Feline and canine leishmaniosis and other vector-borne diseases in the Aeolian Islands: Pathogen and vector circulation in a confined environment. Vet parasitol. 2017;236:144-51.

93. Mylonakis ME, Schreeg M, Chatzis MK, Pearce J, Marr HS, Saridomichelakis $M N$, et al. Molecular detection of vector-borne pathogens in Greek cats. Ticks Tick Borne Dis. 2017;9(2):171-5.

94. Mohebali M, Malmasi A, Khodabakhsh M, Zarei Z, Akhoundi B, Hajjaran $\mathrm{H}$, et al. Feline leishmaniosis due to Leishmania infantum in Northwest Iran: The role of cats in endemic areas of visceral leishmaniosis. Vet Parasitol. 2017;9:13-6.

95. Metzdorf IP, da Costa Lima MSJr, Matos MFC, de Souza Filho AF, de Souza Tsujisaki RA, Franco KG, et al. Molecular characterization of Leishmania infantum in domestic cats in a region of Brazil endemic for human and canine visceral leishmaniasis. Acta trop. 2017;166:121-5.

96. de Mendonça IL, Batista JF, Ribeiro IMM, Rocha FS, Silva SO, Melo MN. Leishmania infantum in domestic cats from the municipality of Teresina, state of Piauí, Brazil. Parasitol Open. 2017;3.

97. Lopes AP, Oliveira AC, Granada S, Rodrigues FT, Papadopoulos E, Schallig $\mathrm{H}$, et al. Antibodies to Toxoplasma gondii and Leishmania spp. in domestic cats from Luanda, Angola. Vet parasitol. 2017;239:15-8.

98. Poffo D, Almeida AB, Nakazato L, Dutra V, Correa SH, Mendonça AJ, et al. Feline immunodeficiency virus (FIV), feline leukaemia virus (FeLV) and Leishmania sp. in domestic cats in the Midwest of Brazil. Pesq Vet Bras. 2017;37(5):491-4.

99. Akhtardanesh B, Sharifi I, Mohammadi A, Mostafavi M, Hakimmipour M, Pourafshar NG. Feline visceral leishmaniasis in Kerman, southeast of Iran: Serological and molecular study. J Vector Borne Dis. 2017;54(1):96-102.

100. Benassi JC, Benvenga GU, Ferreira HL, Pereira VF, Keid LB, Soares R, et al. Detection of Leishmania infantum DNA in conjunctival swabs of cats by quantitative real-time PCR. Exp Parasitol. 2017;177:93-7. 